\title{
Studi Deskriptif dan Analitik COVID-19 pada Anak di Rumah Sakit Umum Daerah Ulin Banjarmasin
}

Edi Hartoyo, ${ }^{1}$ Riswenty Ariyani, ${ }^{2}$ Laila Fitri, ${ }^{2}$ Tania Nurfahmayati, ${ }^{2}$ Septya Aliza Qotrunnada, ${ }^{2}$ Rahmiati ${ }^{3}$

${ }^{1}$ Departemen Ilmu Kesehatan Anak, ${ }^{2}$ Program Studi Kedokteran Program Sarjana, ${ }^{3}$ Departemen Mikrobiologi dan Parasitologi Fakultas Kedokteran Universitas Lambung Mangkurat/RSUD Ulin, Banjarmasin

Latar belakang. Penyakit infeksi COVID-19 adalah penyakit kegawatan disebabkan oleh SARS-CoV-2. Hingga saat ini, data COVID-19 anak masih terbatas.

Tujuan. Mengetahui gambaran klinis, laboratorium, dan tatalaksana COVID-19 anak serta hubungan antara karakteristik demografi dengan derajat keparahan.

Metode. Penelitian retrospektif dengan metode observasional deskriptif digunakan pada gambaran klinis, laboratorium, dan tatalaksana. Metode observasional analitik melalui studi kohort retrospektif untuk menganalisis hubungan antara karakteristik pasien terhadap derajat keparahan. Seluruh pasien anak usia 0-18 tahun terkonfirmasi positif RT-PCR dan memiliki data rekam medis lengkap dan tercatat di RSUD Ulin Banjarmasin periode April 2020-April 2021 diikutsertakan dalam penelitian. Analisis statistik digunakan uji chi-square atau Fisher's exact (tingkat kepercayaan 95\%) dengan menggunakan SPSS for Windows versi 25.0.

Hasil. Dari 32 pasien yang diteliti sebagian besar berusia 0-5 tahun (44\%), mayoritas perempuan (56\%), sebagian besar memiliki komorbid (69\%), dan status gizi anak mayoritas baik (61\%). Berdasarkan parameter karakteristik hanya usia yang ditemukan memiliki pengaruh terhadap derajat keparahan. Gambaran klinis paling umum adalah demam dan pneumonia (44\%). Hasil laboratorium menunjukan adanya peningkatan D-dimer, anemia, dan peningkatan LDH. Terapi yang diberikan sesuai pedoman mencakup terapi utama dan suportif.

Kesimpulan. Gejala klinis COVID-19 bervariasi. Hasil laboratorium sebagian besar normal kecuali beberapa parameter. Tatalaksana dilakukan sesuai pedoman. Tidak ada hubungan signifikan pada jenis kelamin, komorbid, dan status gizi. Sari Pedliatri 2022;23(5):290-8

Kata kunci: anak yang terkonfirmasi COVID-19, derajat keparahan, demografi, profil klinis dan laboratorium, tatalaksana

\section{Descriptive and Analytic Study of COVID-19 in Children at Ulin Hospital Banjarmasin}

Edi Hartoyo, Riswenty Ariyani, Laila Fitri, Tania Nurfahmayati, Septya Aliza Qotrunnada, Rahmiati

Background. COVID-19 is an emerging infection caused by SARS-CoV-2. Thus far, data regarding COVID-19 in children is still limited. Objective. To describe clinical, laboratory, and management features of COVID-19 and the relationship between demographic characteristics and severity.

Methods. This research used a retrospective study with a descriptive observational method that was used for clinical features, laboratory profile, and treatment. Analytic observational with retrospective cohort was used for analyzing the relationships among demographic characteristics and severity. All pediatric patients aged 0-18 years that confirmed positive for RT-PCR and had complete medical record data recorded at the Ulin Hospital Banjarmasin April 2020-April 2021 period were included in this study. Statistical analysis using a chi-square test or Fisher's Exact (95\% confidence level) using SPSS for Windows version 25.0 .

Result. Of the 32 patients studied, most of them were aged $0-5$ years (44\%), the majority were girls (56\%), most had comorbidities (69\%), and the majority of children's nutritional status was good (61\%). Based on the characteristic parameters, only age was found to influence the degree of severity. The most common clinical features were fever and pneumonia (44\%). Laboratory results showed an increase in D-dimer, anemia, and an increase in LDH. Treatment given according to the guidelines includes primary and supportive therapy.

Conclusion. COVID-19 has varied clinical symptoms. Laboratory results were mostly normal except for a few parameters. The treatment is carried out according to the current guidelines. There is no significant relationship between gender, comorbidity and nutritional status. Sari Pediatri 2022;23(5):290-8

Keywords: COVID-19 confirmed children, severity, demographic, clinical and laboratory profile, treatment

Alamat korespondensi: Edi Hartoyo. Departemen Ilmu Kesehatan Anak Fakultas Kedokteran Universitas Lambung Mangkurat. Jl. Veteran No. 128 Banjarmasin 70232 Banjarmasin, Kalimantan Selatan. Email: edihartoyo@yahoo.com 


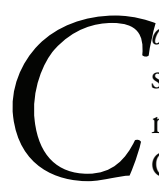

oronavirus disease 2019 (COVID-19) adalah suatu penyakit infeksi kegawatan akibat munculnya virus varian baru, yaitu SARSCoV-2 (Severe Acute Respiratory Distress Syndrome-Coronavirus-2) yang menginfeksi saluran pernapasan bagian bawah. Infeksi ditandai dengan gejala demam, kelelahan, batuk kering, dispneu, dan terkadang disertai gejala gastrointestinal. ${ }^{3,4}$ Virus ini tidak hanya menyerang populasi dewasa, tetapi juga anak-anak. Ikatan Dokter Anak Indonesia (IDAI) melaporkan 12,5\% kasus COVID-19 di Indonesia adalah anak-anak, dengan CFR (case fatality rate) sebesar 3-5\%. ${ }^{5}$ Kasus COVID-19 pada anak telah tersebar di seluruh dunia, tetapi studi epidemiologi COVID-19 pada anak masih belum jelas dikarenakan beragamnya parameter umur, klinis, dan laboratorium. ${ }^{6,7}$

Gambaran klinis pada anak umumnya memiliki gejala ringan. ${ }^{8,9}$ Meskipun begitu, beberapa faktor risiko juga telah diketahui dapat memperburuk klinis COVID-19, seperti usia, jenis kelamin, status gizi, dan komorbid yang menyertai. Kelainan laboratorium yang ditemukan pada anak pun lebih sedikit dan jarang, bahkan beberapa penelitian menunjukkan perbedaan hasil. ${ }^{10-12}$ Informasi terkait pengobatan, seperti penggunaan antivirus, antibiotik, dan glukokortikoid dalam pengobatan COVID-19 pada anak juga masih sangat terbatas.

Hingga saat ini, penelitian COVID-19 masih terfokus pada orang dewasa. Kurangnya rangkuman data mengenai karakteristik umum, gambaran klinis, laboratorium, dan tatalaksana COVID-19 anak di Indonesia, khususnya di daerah Banjarmasin, menjadi dasar dari penelitian ini dengan harapan dapat memberikan tambahan informasi dalam upaya meningkatkan pelayanan kesehatan bagi pasien anak dengan COVID-19.

\section{Metode}

Penelitian ini merupakan penelitian retrospektif dengan metode observasional deskriptif digunakan pada gambaran klinis, laboratorium, dan tatalaksana. Metode observasional analitik melalui studi kohort retrospektif digunakan untuk menganalisis hubungan antara karakteristik pasien terhadap derajat keparahan. Data diperoleh dari rekam medis pasien anak RSUD Ulin Banjarmasin yang terkonfirmasi COVID-19 yang tercatat pada periode April 2020-April 2021. Teknik total sampling digunakan dalam penelitian ini sehingga seluruh pasien anak berusia 0-18 tahun yang terkonfirmasi melalui hasil pemeriksaan RTPCR dan memiliki data rekam medis yang lengkap diikutsertakan dalam penelitian ini. Data yang diambil meliputi usia, jenis kelamin, komorbid, status gizi (berat badan dan panjang/ tinggi badan), gejala klinis yang didapatkan melalui hasil anamnesis dan pemeriksaan fisik, hasil laboratorium (darah rutin, neutrofil, limfosit, ANC, ALC, RNL, CRP, D-dimer, LDH, Kreatinin, Ureum, ALT, AST), serta terapi farmakologi dan non farmakologi sesuai yang terdapat di dalam rekam medis. Gambaran laboratorium yang diambil merupakan hasil pemeriksaan pertama kali saat pasien di rawat di Rumah Sakit. Penilaian status gizi pada anak yang berusia 0-5 tahun didasarkan pada WHO Child Growth Standards 2006 menggunakan indeks berat badan terhadap panjang badan/tinggi badan $(\mathrm{BB} / \mathrm{PB}$ atau $\mathrm{BB} / \mathrm{TB})$. Sementara anak yang berusia 5-18 tahun, didasarkan pada The WHO Reference 2007 menggunakan indeks massa tubuh terhadap usia (IMT/U). Kemudian dikategorikan menjadi tiga sebagai berikut 1) gizi kurang (anak dengan gizi buruk dan gizi kurang), 2) gizi baik, 3) gizi lebih (anak dengan risiko gizi lebih, gizi lebih, dan obesitas). ${ }^{13,14}$ Penentuan derajat keparahan mengacu pada pedoman tatalaksana COVID-19 edisi 3 yang terbagi menjadi 1) asimptomatik-ringan-sedang, 2) berat-kritis. ${ }^{15}$ Analisis statistik yang digunakan untuk mengetahui hubungan antara karakteristik umum dengan derajat keparahan adalah uji chi-square atau Fisher's exact (tingkat kepercayaan 95\%) dengan menggunakan statistical product and service solution SPSS for windows versi 25.0

\section{Hasil}

Sebanyak 64 pasien anak dicurigai COVID-19 selama periode penelitian, 32 anak di antaranya merupakan sampel dalam penelitian ini karena telah memenuhi kriteria inklusi penelitian.

Karakteristik sampel penelitian tertera pada Tabel 1. Usia anak dikelompokkan berdasarkan pembagian usia menurut Departemen Kesehatan tahun 2009, yaitu menjadi 0-5 tahun, >5-11 tahun, dan >11-18 tahun. Pasien sebagian besar berusia 0-5 tahun (44\%) dan semua pasien dengan derajat berat-kritis berasal dari 
kelompok ini. Anak perempuan (56\%) ditemukan lebih banyak daripada anak laki-laki (44\%).

Sebagian besar pasien memiliki komorbid (69\%). Komorbid yang paling banyak ditemukan, yaitu gangguan hemato-onkologi (talasemia B, anemia neonatorum, non hodgkin lymphoma (NHL), myelodysplastic syndrome (MDS), acute lymphoblastic leukemia (ALL)) yang didapatkan pada 34\% anak, penyakit infeksi (demam berdarah dengue (DBD), amebiasis, dan artritis tuberkulosis) pada 9\% anak, asfiksia neonatorum pada $9 \%$ anak, gangguan neurologis (kejang demam kompleks dan vertiginous migraine) pada $9 \%$ anak, dan penyakit lainnya.

Pasien didominasi oleh anak yang berstatus gizi baik $(61 \%)$ dibandingkan dengan gizi kurang dan lebih. Derajat COVID-19 pada anak juga cenderung asimptomatik-ringan-sedang (81\%), dengan 6 anak (19\%) lainnya mengalami derajat berat-kritis. Anak yang berusia muda (0-5 tahun) dan/atau memiliki komorbid cenderung mengalami COVID-19 derajat berat-kritis. Namun, pada penelitian ini hanya parameter usia yang memiliki hubungan bermakna dengan derajat keparahan COVID-19 $(\mathrm{p}<0,05)$. Sementara hasil analisis bivariat pada parameter jenis kelamin, komorbid, dan status gizi dengan derajat keparahan COVID-19 menunjukkan tidak memiliki hubungan yang signifikan ( $>0,05)$.
Penelitian ini menemukan bahwa dari semua pasien gejala yang paling banyak dialami oleh anak dengan COVID-19 adalah demam dan pneumonia yang memiliki frekuensi yang sama, yaitu sebesar 14 (44\%) pasien. Kemudian diikuti dengan gejala batuk sebesar 13 (41\%) pasien. Jumlah pneumonia dengan gejala respirasi khas penanda pneumonia, seperti takipnu dan rhonki terdapat perbedaan karena gejala pneumonia dalam penelitian ini diambil berdasarkan diagnosis dalam rekam medis. Oleh karena itu, beberapa pasien dapat memiliki gambaran pneumonia berdasarkan radiografi tanpa ada gejala khas pneumonia yang menyertai.

Gejala anemia seperti pucat dan konjungtiva anemis juga dapat dijumpai dengan proporsi yang cukup tinggi $11(34 \%)$ hal ini terkait dengan adanya penyakit komorbid yang dialami pasien. Gejala gastrointestinal, seperti mual muntah, dan diare juga cukup banyak ditemukan pada pasien 10 (31\%). Secara lebih rinci gambaran klinis yang ditemukan pada penelitian ini tertera pada Tabel 2.

Hemoglobin dan hematokrit ditemukan sebagian besar berada di bawah rentang nilai normal pada pasien. Eritrosit juga ditemukan mengalami penurunan pada beberapa pasien (26\%). Trombosit, leukosit, jumlah neutrofil relatif dan absolut, jumlah limfosit relatif dan absolut, serta RNL ditemukan sebagian besar normal pada pasien. Kadar CRP ditemukan normal pada 82\%

Tabel 1. Karakteristik umum pasien COVID-19 anak

\begin{tabular}{|c|c|c|c|c|}
\hline \multirow[t]{2}{*}{ Parameter } & \multirow[t]{2}{*}{$\mathrm{N}$} & \multicolumn{2}{|c|}{ Derajat keparahan } & \multirow[t]{2}{*}{$\mathrm{p}$} \\
\hline & & Asimptomatik-ringan-sedang & Berat-kritis & \\
\hline Jumlah pasien & 32 & 26 & 6 & \\
\hline Usia pasien, n (\%) & 32 & & & $0,009^{*}$ \\
\hline $0-5$ tahun & & $8(25)$ & $6(19)$ & \\
\hline$>5-11$ tahun & & $5(16)$ & 0 & \\
\hline$>11-18$ tahun & & $13(40)$ & 0 & \\
\hline Jenis kelamin, $\mathrm{n}(\%)$ & 32 & & & $1,000^{* *}$ \\
\hline Laki-laki & & $11(35)$ & $3(9)$ & \\
\hline Perempuan & & $15(47)$ & $3(9)$ & \\
\hline Komorbid, n (\%) & 32 & & & $0,637^{* *}$ \\
\hline Ada komorbid & & $17(53)$ & $5(16)$ & \\
\hline Tanpa komorbid & & $9(28)$ & $1(3)$ & \\
\hline Status gizi, $\mathrm{n}(\%)$ & 31 & & & $0,095^{*}$ \\
\hline Kurang & & $7(23)$ & 0 & \\
\hline Baik & & $13(42)$ & $6(19)$ & \\
\hline Lebih & & $5(16)$ & 0 & \\
\hline
\end{tabular}

${ }^{*}$ Uji chi-square, ${ }^{* *}$ Uji Fisher's exact 
Edi Hartoyo dkk: Studi deskriptif dan analitik COVID-19 pada anak di RSUD Ulin Banjarmasin

pasien dan meningkat pada $18 \%$ pasien. D-dimer dan LDH berada di atas nilai normal pada banyak pasien, berturut-turut pada 59\% dan 50\% pasien. Fungsi ginjal dan hati ditemukan mengalami perubahan pada sebagian pasien. Ureum ditemukan meningkat pada $38 \%$ pasien, kreatinin meningkat pada $17 \%$ pasien, AST meningkat pada $48 \%$ pasien, dan ALT meningkat pada $37 \%$ pasien. Gambaran laboratorium pasien lebih rinci tertera pada Tabel 3.

Berdasarkan hasil penelitian yang didapatkan, jenis obat yang paling banyak digunakan dalam tatalaksana farmakologis pasien anak dengan COVID-19 adalah vitamin dan mineral sebesar $93 \%$ dengan jenis terbanyak yang digunakan adalah zinc (78\%), pemberian antibiotik sebanyak $79 \%$ dengan jumlah terbanyak adalah azithromycin (59\%) dan antivirus sebanyak 59\% dengan jenis terbanyak adalah aluvia (47\%). Tatalaksana COVID-19 anak secara rinci tertera pada Tabel 4.

\section{Pembahasan}

Hasil penelitian kami berbeda dengan penelitian sebelumnya dilihat dari proporsi kasus pada tiap parameter. Kejadian COVID-19 dapat terjadi pada anak dalam kelompok umur berapapun, baik laki-laki maupun perempuan. ${ }^{16,17}$ Namun, anak lebih rentan terinfeksi COVID-19 jika berusia >5-16 tahun, lakilaki, memiliki komorbid, dan berstatus gizi lebih/ obesitas..$^{8,18,19}$

Parameter usia dengan tingkat keparahan COVID-19 menunjukkan hubungan yang bermakna. Serupa dengan laporan penelitian Bellino dkk ${ }^{20}$ di Italia bahwa anak usia lebih muda berisiko mengalami COVID-19 yang parah. Sebaliknya, seiring bertambahnya usia anak maka semakin rendah risiko keparahan. Kami tidak mendapatkan hubungan antara jenis kelamin, komorbid, dan status gizi dengan derajat keparahan COVID-19.

Laki-laki diketahui cenderung lebih rentan terinfeksi COVID-19 dan mengalami komplikasi yang lebih berat daripada perempuan. Hal ini dikarenakan tingginya ekspresi dan aktivitas yang berlebih dari ACE$2 .{ }^{18}$ Secara teori, laki-laki lebih rentan, tetapi penelitian terdahulu menunjukkan perbedaan jumlah kasus pada laki-laki dan perempuan yang tidak terlalu bermakna serta memiliki kerentanan yang sama terhadap
Tabel 2. Gambaran klinis pasien COVID-19 anak

\begin{tabular}{|c|c|}
\hline Gambaran klinis & $\mathrm{n}(\%)$ \\
\hline Demam & $14(44)$ \\
\hline Pneumonia* & $14(44)$ \\
\hline Batuk & $13(41)$ \\
\hline Gejala anemia** & $11(34)$ \\
\hline Mual muntah & $10(31)$ \\
\hline Diare & $10(31)$ \\
\hline Retraksi dada & $6(19)$ \\
\hline Nyeri abdomen & $6(19)$ \\
\hline Pilek & $5(15)$ \\
\hline Anosmia & $4(12)$ \\
\hline Fatigue & $4(12)$ \\
\hline Rhonki & $4(12)$ \\
\hline Takipnu & $4(12)$ \\
\hline Sesak & $4(12)$ \\
\hline Desaturasi & $4(12)$ \\
\hline Pusing & $3(9)$ \\
\hline Hepatosplenomegali & $3(9)$ \\
\hline Gatal & $3(9)$ \\
\hline Ageusia & $2(6)$ \\
\hline Pernapasan cuping hidung & $2(6)$ \\
\hline Kejang & $2(6)$ \\
\hline ARDS & $2(6)$ \\
\hline Gangguan koagulasi & $2(6)$ \\
\hline Penurunan kesadaran & $1(3)$ \\
\hline Nyeri tenggorokan & $1(3)$ \\
\hline Melena & $1(3)$ \\
\hline Nyeri dan edem genu*** & $1(3)$ \\
\hline
\end{tabular}

COVID-19. ${ }^{17,21,22}$

Secara teori, komorbid diketahui dapat berperan terhadap derajat keparahan, hal ini terkait dengan peningkatan ekspresi ACE-2 akibat beberapa pengobatan komorbid maupun komorbid itu sendiri. Penurunan respon imun dan proteksi lebih lemah juga menjadi faktor kerentanan terhadap terjadinya perburukan, seperti pada pasien dengan komorbid kanker. ${ }^{23}$ Penelitian kami menunjukkan bahwa derajat berat-kritis didominasi oleh pasien dengan komorbid, meskipun begitu berdasarkan analisis tidak didapatkan hubungan bermakna. Hal ini selaras dengan penelitian Kapoor $\mathrm{dkk}^{24}$ yang melaporkan tidak ada perbedaan antara derajat keparahan COVID-19 pada anak dengan komorbid dan tanpa komorbid. 
Tabel 3. Gambaran laboratorium pasien COVID-19 anak

\begin{tabular}{|c|c|c|c|c|}
\hline \multirow[t]{2}{*}{ Parameter laboratorium } & \multirow[t]{2}{*}{$\mathrm{N}$} & \multicolumn{3}{|c|}{$\mathrm{n}(\%)$} \\
\hline & & $<$ Normal & Normal & $>$ Normal \\
\hline Hemoglobin $(\mathrm{g} / \mathrm{dL})^{*}$ & 31 & $16(52)$ & $15(48)$ & \\
\hline Hematokrit (\%)* & 31 & $15(48)$ & $15(48)$ & $1(3)$ \\
\hline Eritrosit (juta/L)* & 31 & $8(26)$ & $20(64)$ & $3(10)$ \\
\hline Trombosit (ribu/L)* & 31 & $5(16)$ & $22(71)$ & $4(13)$ \\
\hline Leukosit (ribu/L)* & 31 & $6(19)$ & $23(74)$ & $2(6)$ \\
\hline Neutrofil (\%)* & 31 & $2(6)$ & $26(84)$ & $3(10)$ \\
\hline Limfosit $(\%)^{*}$ & 31 & $5(16)$ & $23(74)$ & $3(10)$ \\
\hline ANC (ribu/L)* & 31 & $4(13)$ & $25(81)$ & $2(6)$ \\
\hline $\operatorname{ALC}(\mathrm{ribu} / \mathrm{L})^{* *}$ & 31 & $5(16)$ & $26(84)$ & \\
\hline $\mathrm{RNL}^{* *}$ & 31 & & $24(77)$ & $7(23)$ \\
\hline $\mathrm{CRP}(\mathrm{mg} / \mathrm{L})^{* *}$ & 28 & & $23(82)$ & $5(18)$ \\
\hline D-dimer $(\mathrm{mg} / \mathrm{L})^{*}$ & 22 & & $9(41)$ & $13(59)$ \\
\hline $\mathrm{LDH}(\mathrm{U} / \mathrm{L})^{*}$ & 26 & 0 & $13(50)$ & $13(50)$ \\
\hline Kreatinin $(\mathrm{mg} / \mathrm{dL})^{*}$ & 24 & $4(17)$ & $16(67)$ & $4(17)$ \\
\hline Ureum $(\mathrm{mg} / \mathrm{dL})^{*}$ & 24 & 0 & $15(62)$ & $9(38)$ \\
\hline $\operatorname{ALT}(\mathrm{U} / \mathrm{L})^{*}$ & 27 & $2(7)$ & $15(56)$ & $10(37)$ \\
\hline $\operatorname{AST}(\mathrm{U} / \mathrm{L})^{*}$ & 27 & 0 & $14(52)$ & $13(48)$ \\
\hline
\end{tabular}

${ }^{*}$ Rujukan nilai normal berdasarkan usia dan jenis kelamin-Hemoglobin 0-30 hari (15-22 g/dL), 1 bulan (10,5-14 g/dL), 2-6 bulan (9,5-13,5 g/dL), 7 bulan-2 tahun (10,5-14 g/dL), 3-6 tahun (11,5-14,5 g/dL), 7-12 tahun (11,5-15,5 g/dL), $13-18$ tahun laki-laki (13-16 g/dL), 13-18 tahun perempuan (12-16 g/dL)-Hematokrit 0-30 hari (44-70\%), 1 bulan (32-42\%), 2-6 bulan (29-41\%), 7 bulan-2 tahun (33-39\%), 3-6 tahun (34-40\%), 7-12 tahun (35-45\%), 13-18 tahun laki-laki (37-49\%), 13-18 tahun perempuan (36-45\%)-Eritrosit 0-30 hari (4,1-6,7 juta/L), 1 bulan (3-5,4 juta/L), 2-6 bulan (2,7-4,5 juta/L), 7 bulan-2 tahun (3,7-5,3 juta/L), 3-6 tahun (3,9-5,3 juta/L), 7-12 tahun (4-5,2 juta/L), 13-18 tahun laki-laki (4,5-5,3 juta/L), 13-18 tahun perempuan (4,1-5,1 juta/L)-Trombosit 150-450 ribu/L-Leukosit 0-30 hari (9,1-34 ribu/L), 1 bulan (5-19,5 ribu/L), 2-11 bulan (6-17,5 ribu/L), 1-12 tahun (5-14,5 ribu/L), 13-18 tahun (4,5-13,5 ribu/L)-Neutrofil 0-30 hari (32-75\%), 1 bulan (2050,5\%), 2-11 bulan (20-51,8\%), 1-6 tahun (37-72\%), 7-18 tahun (33-77\%)-Limfosit 0-30 hari (25-37\%), 1 bulan (28-84\%), 2-11 bulan (34-88\%), 1-6 tahun (17-67\%), 7-12 tahun (15-61\%), 13-18 tahun (15-55\%)-ANC 0-30 hari (6-23,5 ribu/L), 1 bulan (1-9 ribu/L), 2-11 bulan (1-8,5 ribu/L), 1-12 tahun (1,5-8 ribu/L), 13-18 tahun (1,8-8 ribu/L)-D-dimer $<0,5 \mathrm{mg} / \mathrm{L}-$ LDH bayi baru lahir (300-1500 IU/L), anak-anak (110-295 U/L)-Ureum 0-15 tahun (2-23 mg/dL), 16-18 tahun (4-18 mg/ dL)-Kreatinin 0-14 hari (0,3-0,9 mg/dL), 15 hari-1 tahun (0,1-0,4 mg/dL), 2-4 tahun (0,2-0,4 mg/dL), 5-11 tahun $(0,3-0,6$ $\mathrm{mg} / \mathrm{dL}), 12-14$ tahun $(0,5-0,8 \mathrm{mg} / \mathrm{dL})$ 15-18 tahun laki-laki $(0,6-1 \mathrm{mg} / \mathrm{dL}), 15-18$ tahun perempuan $(0,5-0,8 \mathrm{mg} / \mathrm{dL})-\mathrm{AST}$ anak 8-38 U/L, bayi baru lahir 4x lipat nilai normal anak-ALT anak 10-35 U/L, bayi baru lahir 2x lipat nilai normal anak.

**Rujukan nilai beresiko tinggi COVID-19-ALC $<1,5$ ribu/L-RNL >=3,13-CRP >10 mg/L.

Penelitian Allard $\mathrm{dkk}^{25}$ juga melaporkan tidak didapatkan hubungan antara malnutrisi dengan derajat keparahan COVID-19. Hubungan ini merupakan suatu hubungan yang saling memengaruhi, ketika malnutrisi berperan sebagai variabel kontinu yang menjadi penyebab atau akibat dari keparahan COVID-19. Sedangkan penelitian lain di Inggris oleh Gao $\mathrm{dkk}^{26}$ menyatakan bahwa gizi lebih/obesitas diketahui sebagai faktor risiko keparahan COVID-19 serta menunjukkan adanya hubungan linear antara peningkatan IMT (indeks massa tubuh) dengan kejadian masuk ICU (intensive care unit) karena COVID-19. Pada individu yang obesitas telah terjadi inflamasi kronis stadium rendah, ditandai dengan peningkatan kadar penanda inflamasi sistemik. Kondisi ini meningkatkan respon inflamasi apabila terinfeksi SARS-CoV-2 sehingga memicu terjadinya badai sitokin. ${ }^{27}$

Manifestasi klinis COVID-19 anak umumnya tidak memiliki gejala khas dan memiliki beragam gejala dengan spektrum luas, mulai demam, gangguan respirasi, gangguan gastrointestinal hingga gangguan 
Tabel 4. Tatalaksana pasien COVID-19 anak

\begin{tabular}{|c|c|}
\hline Tatalaksana & $\mathrm{n}(\%)$ \\
\hline \multicolumn{2}{|l|}{ Farmakologi } \\
\hline Antivirus & $19(59)$ \\
\hline Aluvia & $15(47)$ \\
\hline Favipiravir & $3(9)$ \\
\hline Oseltamivir & $1(3)$ \\
\hline Antibiotik & $25(78)$ \\
\hline Azithromycin & 19(59) \\
\hline Ceftriaxone & $13(41)$ \\
\hline Kortikosteroid & $4(13)$ \\
\hline Deksametasone & $2(6)$ \\
\hline Metilprednisolon & $2(6)$ \\
\hline Vitamin & $30(93)$ \\
\hline Vitamin C & $25(72)$ \\
\hline Zink & $23(78)$ \\
\hline \multicolumn{2}{|l|}{ Obat-obatan lain } \\
\hline \multicolumn{2}{|l|}{ Antipiretik } \\
\hline Parasetamol & $8(25)$ \\
\hline \multicolumn{2}{|l|}{ Antitusif ekspektoran } \\
\hline Ambroxol & $6(19)$ \\
\hline Salbutamol & $6(19)$ \\
\hline \multicolumn{2}{|l|}{ Non-farmakologi } \\
\hline Pemberian oksigen & $6(18)$ \\
\hline Nasal canula (NC) & $5(16)$ \\
\hline CPAP & $3(9)$ \\
\hline Pemberian cairan & $21(65)$ \\
\hline D5 & $15(47)$ \\
\hline RL & $4(13)$ \\
\hline KAEN & $3(9)$ \\
\hline $\mathrm{NaCl}$ & $2(6)$ \\
\hline $\mathrm{D} 10 \%+\mathrm{KCL}+\mathrm{NaCl}+\mathrm{Ca}$ glukonas & $1(3)$ \\
\hline Pemberian nutrisi & $32(100)$ \\
\hline Oral normal & $27(84)$ \\
\hline Parenteral & $3(9)$ \\
\hline \multicolumn{2}{|l|}{ Enteral: } \\
\hline OGT & $4(13)$ \\
\hline NGT & $1(3)$ \\
\hline
\end{tabular}

neurologis dan gejala lain dapat ditemukan. Pada penelitian kami, demam merupakan gejala klinis paling banyak dijumpai kemudian diikuti dengan pneumonia dan gejala respirasi lain. Demam merupakan gejala paling umum ditemukan pada anak dalam penelitian kami dan sejalan dengan hasil penelitian Yazidi $\mathrm{dkk}^{28}$ yang juga melaporkan bahwa gejala paling umum COVID-19 anak adalah demam, baik riwayat demam maupun demam yang terkonfirmasi. Mekanisme demam ini dapat dijelaskan dengan teori mengenai respon awal imun tubuh melawan infeksi sehingga terjadi pengeluaran sitokin yang dapat meningkatkan termostat sehingga terjadi demam. ${ }^{29}$

Gejala terkait sistem respirasi, seperti pneumonia dan batuk dipengaruhi oleh tingginya ekspresi ACE2 , yaitu enzim yang berperan dalam proses perlekatan virus dengan sel inang. Enzim ACE-2 ini diekspresikan dalam berbagai organ, mulai dari saluran respirasi juga saluran cerna, tetapi paling tinggi dapat ditemukan di saluran respirasi terutama pada epitelium saluran napas atas dan paru-paru. ${ }^{29,30}$ Penelitian kami juga melaporkan beberapa gejala yang jarang pada kasus COVID-19. Gejala anemia adalah salah satu contohnya, memiliki proporsi cukup besar, yaitu 11 (34\%). Hal tersebut diakibatkan sebagian besar pasien memiliki komorbid berupa gangguan hematologi dan onkologi sehingga manifestasi terkait penyakit komorbid juga bisa ditemukan pada pasien.

Hasil pemeriksaan laboratorium yang ditemukan sebagian besar normal. Namun banyak ditemukan anak yang mengalami anemia dan penurunan hematokrit. Pada COVID-19 dapat terjadi penurunan hemoglobin dan hematokrit melalui berbagai mekanisme, seperti terganggunya eritropoiesis akibat rusaknya jaringan ginjal dan sumsum tulang karena serangan SARS-CoV-2 secara langsung atau akibat sitokin pro inflamasi yang dapat menyebabkan kerusakan. Selain itu, metabolisme besi yang abnormal pada COVID-19 akibat kelebihan produksi IL-6 juga dapat mengganggu eritropoiesis. ${ }^{31-34}$

Penelitian lain menunjukkan hasil yang berbeda dengan penelitian kami yang melaporkan bahwa hemoglobin dan hematokrit pada COVID-19 anak umumnya memiliki nilai yang normal. ${ }^{12,35}$ Rendahnya temuan anemia pada COVID-19 dapat berhubungan dengan masa hidup eritrosit yang panjang dan adanya proliferasi kompensasi eritrosit akibat hipoksia yang terjadi pada pasien COVID-19. ${ }^{34}$ Pasien yang mengalami anemia dan penurunan hematokrit hampir semuanya memiliki komorbid gangguan hemato-onkologi yang diketahui dapat menyebabkan anemia dan penurunan hematokrit. Temuan ini belum dapat dipastikan apakah memang disebabkan karena COVID-19 yang dialami pasien atau karena komorbid.

Trombosit, leukosit, neutrofil, limfosit, RNL, dan CRP sebagian besar normal. Pasien yang sedikit memiliki jumlah trombosit, neutrofil, limfosit, RNL, dan CRP yang tidak normal pada pasien COVID-19 
anak dapat dikaitkan dengan rendahnya COVID-19 yang parah pada anak. ${ }^{12,32,36,37}$

D-dimer sebagian besar ditemukan meningkat pada pasien. Peningkatan D-dimer menjadi penanda kecurigaan trombosis dan menjadi prediktor terjadinya ARDS, keperluan perawatan intensif, dan kematian pada COVID-19. ${ }^{38}$ Beberapa penelitian menunjukkan adanya hubungan yang bermakna antara peningkatan D-dimer dengan keparahan COVID-19, seperti penelitian Saleh dkk ${ }^{39}$ dan Qiu dkk. ${ }^{8}$ Namun, terdapat penelitian lain yang tidak menemukan hubungan yang bermakna antara keparahan dengan peningkatan D-dimer, seperti penelitian Graff dkk. ${ }^{40}$ Penelitian lebih lanjut mengenai perubahan $\mathrm{D}$-dimer perlu dilakukan pada sampel yang lebih banyak dan menyingkirkan komorbid. Jumlah anak yang mengalami peningkatan LDH sama dengan jumlah anak dengan LDH normal. Sekresi LDH disebabkan karena nekrosis membran sel yang menandakan infeksi virus atau kerusakan paru meskipun tidak spesifik disebabkan karena COVID-19. ${ }^{41}$

Tatalaksana COVID-19 pada anak dilakukan dengan pemberian tatalaksana utama (pemberian antivirus, antibiotik, kortikosteroid, vitamin dan mineral) dan tatalaksana suportif (pemberian obat simptomatik, oksigen, cairan dan nutrisi). Aluvia (lopinavir/ritonavir) merupakan jenis antivirus terbanyak dipakai, yang bekerja dengan cara menghambat protease (protease inhibitor) dan digunakan pada pasien yang terinfeksi human immunodeficiency virus. Menurut studi in vitro yang dilakukan oleh Kang $\mathrm{dkk}^{42}$ mengatakan bahwa Lopinavir/ritonavir dapat mengurangi efek sitopatik dan viral load dari SARS-CoV-2. Terapi antibiotik dilakukan untuk mencegah terjadinya kejadian ko-infeksi terhadap COVID-19. Hasil penelitian yang dilakukan oleh Zhu dkk ${ }^{43}$ di Jiangsu China menunjukkan bahwa koinfeksi bakteri merupakan kasus ko-infeksi terbanyak, terjadi pada 236 pasien $(91,8 \%)$ sehingga pemilihan antibiotik dipertimbangkan berdasarkan diagnosis klinik, epidemiologi penyakit, data kepekaan kuman lokal rumah sakit, dan paduan terapi. Pemberian kortikosteroid tidak digunakan sebagai tatalaksana COVID-19, tetapi digunakan sebagai pengobatan terhadap komorbid yang diderita pasien. Pada pasien anak dengan COVID-19 hampir seluruh pasien diberikan vitamin dan mineral, pemberian vitamin dan mineral ini diusulkan untuk mengurangi durasi dan tingkat keparahan infeksi virus dengan meningkatkan respon imun.
Pemberian nutrisi pada pasien COVID-19 di RSUD Ulin Banjarmasin mayoritas melalui asupan oral (normal). Pemberian nutrisi parenteral diberikan pada pasien neonatus yang mengalami sepsis. Sementara pemberian nutrisi melalui OGT dan NGT diberikan kepada pasien yang mengalami kesulitan makan karena pada pasien dengan saturasi oksigen yang tidak memadai akan memungkinkan mengeluh anoreksia, cepat kenyang, malaise, kembung, konstipasi atau diare yang nantinya akan berpengaruh terhadap asupan nutrisi pasien. ${ }^{44}$ Pemberian oksigen kepada pasien anak dengan COVID-19 diberikan kepada anak dengan derajat penyakit berat-kritis yang memiliki gejala klinis sesak napas dengan saturasi $\mathrm{O} 2<95 \%$. Pemberian O2 sebagian besar melalui nasal kanul (16\%), dan pada kasus bayi baru lahir dengan RDS (respiratory distress syndrome), diberikan melalui CPAP.

Penelitian kami memiliki beberapa keterbatasan, yaitu komorbid pasien yang tidak dieksklusi. Hal tersebut dapat mengaburkan gambaran klinis, hasil laboratorium, dan analisis hubungan antara karakteristik umum pasien dengan derajat keparahan. Beberapa rekam medis yang tidak memuat data pengukuran antropometri juga menjadi keterbatasan dalam penelitian ini. Penelitian lebih lanjut masih diperlukan untuk menyempurnakan dan mengembangkan hasil penelitian ini. Penggunaan data primer disarankan untuk mengurangi bias penelitian serta jumlah sampel yang lebih besar dan tidak terbatas pada tempat tertentu diperlukan agar hasil yang didapatkan mampu menggambarkan keseluruhan populasi COVID-19 pada anak.

\section{Kesimpulan}

Penyakit COVID-19 pada anak sebagian besar merupakan kasus ringan hingga sedang dengan temuan gejala klinis paling umum adalah demam dan pneumonia. Gambaran laboratorium yang paling banyak ditemukan adalah peningkatan D-dimer, anemia, dan peningkatan LDH. Terapi yang diberikan pada anak umumnya berupa terapi utama dan suportif. Usia diketahui memengaruhi derajat keparahan COVID-19 pada anak. Namun, jenis kelamin, komorbid, dan status gizi tidak menunjukkan hubungan yang bermakna. 


\section{Daftar pustaka}

1. Sun Y, Dong Y, Wang L, dkk. Characteristics and prognostic factors of disease severity in patients with COVID-19: The Beijing experience. J Autoimmun 2020;112:102473.

2. Jutzeler CR, Bourguignon L, Weis C V, dkk. Comorbidities, clinical signs and symptoms, laboratory findings, imaging features, treatment strategies, and outcomes in adult and pediatric patients with COVID-19: A systematic review and meta-analysis. Travel Med Infect Dis 2020;37:101825.

3. Tsankov BK, Allaire JM, Irvine MA, dkk. Severe COVID-19 infection and pediatric comorbidities: A systematic review and meta-analysis. Int J Infect Dis 2021;103:246-56.

4. Wu Y-C, Chen C-S, Chan Y-J. The outbreak of COVID-19. J Chinese Med Assoc 2020;83:217-20.

5. Mazrieva E. Kematian anak akibat COVID-19 di Indonesia tertinggi di dunia, IDAI: Jaga anak kita! [Internet]. 23 Juni 2021. 2021 [cited 2021 Aug 7]. Didapat dari: https:// www.voaindonesia.com/alkematian-anak-akibat-covid-19-diindonesia-tertinggi-di-duniaidai-jaga-anak-kita-15939379.html

6. Tezer H, Bedir Demirdağ T. Novel coronavirus disease (Covid-19) in children. Turkish J Med Sci 2020;50:592-603.

7. Shane AL, Sato AI, Kao C, dkk. A pediatric infectious disease perspective of SARS-CoV-2 and COVID-19 in children. J Pediatric Infect Dis Soc 2020;9:596-608.

8. Qiu H, Wu J, Hong L, Luo Y, Song Q, Chen D. Clinical and epidemiological features of 36 children with coronavirus disease 2019 (COVID-19) in Zhejiang, China: an observational cohort study. Lancet Infect Dis 2020;20:689-96.

9. Zheng F, Liao C, Fan Q, dkk. Clinical Characteristics of Children with Coronavirus Disease 2019 in Hubei, China. Curr Med Sci 2020;40:275-80.

10. Henry BM, Lippi G, Plebani M. Laboratory abnormalities in children with novel coronavirus disease 2019. Clin Chem Lab Med 2020;58:1135-8.

11. Henry BM, Benoit SW, de Oliveira MHS, dkk. Laboratory abnormalities in children with mild and severe coronavirus disease 2019 (COVID-19): A pooled analysis and review. Clin Biochem 2020;81:1-8.

12. Bourkhissi L, Fakiri K EL, Nassih H, dkk. Laboratory abnormalities in children with novel Coronavirus Disease 2019. Clin Med Insights Pediatr 2020;14:117955652095517.

13. World Health Organization. Child growth standards: Weight for length/height [Internet]. 2006 [cited 2021 Aug 8]. Didapat dari:https://www.who.int/tools/child-growth-standards/standards/ weight-for-length-height.

14. Menteri Kesehatan RI. PERMENKES RI nomor 2 tahun 2020 tentang standar antropometri anak. Diakses 23 May 2021. Didapat dari: http://hukor.kemkes.go.id/uploads/produk_hukum/ PMK_No_2_Th_2020_ttg_Standar_Antropometri_Anak.pdf.

15. Burhan E, Susanto AD, Nasution SA, dkk. Pedoman tatalaksana COVID-19. Edisi ke-3. Jakarta: PDPI, PERKI, PAPDI, PERDATIN, IDAI; 2020.h.149.

16. El Fakiri K, Nassih H, Ait Sab I, Draiss G, Bouskraoui M. Epidemiology and clinical features of coronavirus disease 2019 in Moroccan children. Indian Pediatr 2020;57:808-10.
17. Jin JM, Bai P, He W, dkk. Gender differences in patients with COVID-19: Focus on severity and mortality. Front Public Health 2020;8:152.

18. Rashedi J, Poor BM, Asgharzadeh V, dkk. Risk factors for covid-19. Infez Med 2020;28:469-74.

19. Jung C-Y, Park H, Kim DW, dkk. Association between body mass index and risk of coronavirus disease 2019 (COVID19): A nationwide case-control study in South Korea. Clin Infect D 2020;73:e1855-62.

20. Bellino S, Punzo O, Rota MC, dkk. COVID-19 disease severity risk factors for pediatric patients in Italy. Pediatrics 2020;146:e2020009399.

21. Tagarro A, Epalza C, Santos M, Sanz-Santaefeumia FJ, Otheo E, Moraleda C. Screening and severity of coronavirus disease 2019 (COVID-19) in children in Madrid, Spain. JAMA Pediatr 2021;175:316.

22. Bolaños-Almeida CE, Espitia Segura OM. Clinical and epidemiologic analysis of covid-19 children cases in Colombia PEDIACOVID. Pediatr Infect Dis J 2020;40:7-11.

23. Susilo A, Rumende CM, Pitoyo CW, dkk. Coronavirus Disease 2019: Tinjauan Literatur Terkini. J Penyakit Dalam Indones 2020;7:45-67.

24. Kapoor D, Kumar V, Pemde H, Singh P. Impact of Comorbidities on Outcome in Children With COVID-19 at a Tertiary Care Pediatric Hospital. Indian Pediatr 2021;58:572-5.

25. Allard L, Ouedraogo E, Molleville J, dkk. Malnutrition: Percentage and association with prognosis in patients hospitalized for coronavirus disease 2019. Nutrients 2020;12:1-14.

26. Gao M, Piernas C, Astbury NM, dkk. Associations between body-mass index and COVID-19 severity in 6.9 million people in England: a prospective, community-based, cohort study. Lancet Diabetes Endocrinol 2021;9:350-9.

27. Aqmarina NW, Risanti ED, Mahmudah IN, Jatmiko SW. Obesitas sebagai faktor risiko keparahan pada COVID-19. Prosiding dari the 13th University Research Colloquium; Klaten,Indonesia; 20 Maret 2021.h.371-7.

28. Al Yazidi LS, Al Hinai Z, Al Waili B, dkk. Epidemiology, characteristics and outcome of children hospitalized with COVID- 19 in Oman: A multicenter cohort study. Int J Infect Dis 2021;104:655-60.

29. Parasher A. COVID-19: Current understanding of its Pathophysiology, Clinical presentation and Treatment. Postgrad Med J 2021;97:312-20.

30. Wiersinga WJ, Rhodes A, Cheng AC, Peacock SJ, Prescott HC. Pathophysiology, transmission, diagnosis, and treatment of coronavirus disease 2019 (COVID-19): A Review. JAMA - J Am Med Assoc 2020;324:782-93.

31. Bergamaschi G, Borrelli de Andreis F, Aronico N, dkk. Anemia in patients with Covid-19: pathogenesis and clinical significance. Clin Exp Med 2021;21:239-46.

32. Liu L, She J, Bai Y, Liu W. SARS-CoV-2 Infection : Differences in hematological parameters between adults and children. Int J Gen Med 2021;3035-47.

33. Lippi G, Plebani M. Laboratory abnormalities in patients with COVID-2019 infection. Clin Chem Lab Med 2020;58:1131-4.

34. Liu X, Zhang R, He G. Hematological findings in coronavirus 
disease 2019: indications of progression of disease. Ann Hematol 2020;99:1421-8.

35. Xu H, Liu E, Xie J, dkk. A follow-up study of children infected with SARS-CoV-2 from western China. Ann Transl Med 2020;8:623.

36. Hasma R, Rikarni, Yulia D. Analisis jumlah trombosit pada pasien terinfeksi severe acuterespiratory syndrome coronavirus 2 (SARS-COV-2). Majalah Kedokteran Andalas 2021;44:316-24.

37. Tjahyadi RM, Astuti T, Listyoko AS. COVID-19 : Correlation between CRP and LDH to disease severity and mortality in hospitalized COVID-19 patients. Medica Hosp J Clin Med 2020;7:144-9.

38. Willim HA, Hardigaloeh AT, Supit AI, Handriyani. Koagulopati pada Coronavirus Disease-2019 (COVID-19): Tinjauan pustaka. Intisari Sains Medis 2020;11:749-56.

39. Saleh NY, Aboelghar HM, Salem SS, dkk. The severity and atypical presentations of COVID-19 infection in pediatrics. BMC Pediatr 2021;21:144.

40. Graff K, Smith C, Silveira L, dkk. Risk factors for severe
COVID-19 in children. Pediatr Infect Dis J 2021;40:137-45.

41. Wu MY, Yao L, Wang Y, dkk. Clinical evaluation of potential usefulness of serum lactate dehydrogenase (LDH) in 2019 novel coronavirus (COVID-19) pneumonia. Respir Res 2020;21:1-6.

42. Kang CK, Seong MW, Choi SJ, dkk. In vitro activity of lopinavir/ritonavir and hydroxychloroquine against severe acute respiratory syndrome coronavirus 2 at concentrations achievable by usual doses. Korean J Intern Med 2020;35:728-87.

43. Zhu X, Ge Y, Wu T, dkk. Co-infection with respiratory pathogens among COVID-2019 cases. Virus Res 2020;285:198005.

44. Republic of Kenya Ministry of Health. Guidance For Nutrition Management Of Covid-19 For Health Workers In Covid-19 Treatement And Isolation Centres[Internet]. COVID-19 Protocols and Guidlines. 2020 [Cited 3 December 2021]. Didapatkan dari: https://www.health.go.ke/wp-content/uploads/2020/03/finalguidance-for-covid-19-nutrition-management.pdf. 